\title{
Tree species of concern in New Brunswick, Canada. II. Guidelines for conservation of genetic resources
}

\author{
by J.A. Loo ${ }^{1,2}$, T.L. Beardmore ${ }^{1}$, J.D. Simpson ${ }^{1}$ and D.A. McPhee ${ }^{1}$
}

\begin{abstract}
Guidelines were developed by the New Brunswick Forest Gene Conservation Working Group for conserving genetic resources of four native tree species in New Brunswick. Gene conservation guidelines for three of these species aim to maintain sufficient gene pools of known or putatively resistant stock to retain or develop the potential for restoration. Natural populations of American beech (Fagus grandifolia) are known to have genotypes resistant to the beech scale at low frequencies. Gene conservation approaches include in situ and ex situ measures, including resistance breeding. White elm (Ulmus americana) demonstrates a degree of resistance to Dutch elm disease (DED), and will benefit from a mixture of in situ and ex situ conservation measures. Resistance to butternut canker has not yet been demonstrated in populations of butternut (Juglans cinerea), but ex situ conservation of putatively resistant genotypes will be of increasing importance as the frequency of butternut canker escalates. Bur oak (Quercus macrocarpa), threatened by small population size, habitat loss, and ongoing development, requires primarily in situ conservation and restoration efforts.
\end{abstract}

Key words: American beech, bur oak, butternut, disease resistance, ex situ, gene conservation guidelines, genetic resources, in situ, restoration, white elm

\section{RÉSUMÉ}

Des directives ont été élaborées par le Groupe de travail de conservation du patrimoine génétique forestier du NouveauBrunswick dans le but de préserver les ressources génétiques de quatre espèces indigènes du Nouveau-Brunswick. Les directives de conservation du patrimoine génétique de trois de ces espèces visent à maintenir des pools génétiques suffisants des stocks connus pour être ou pouvant être résistants afin de maintenir ou de développer leur potentiel en matière de reboisement. Les populations naturelles de hêtre à grandes feuilles (Fagus grandifolia) sont connues pour avoir des génotypes résistants à la maladie corticale du hêtre à faibles fréquences. Les approches de préservation génétique comprennent des mesures in situ et ex situ, ainsi que des croisements entre individus résistants. L'orme d'Amérique (Ulmus americana) démontre une certaine résistance à la maladie hollandaise de l'orme et bénéficiera d'un ensemble de mesures de conservation in situ et ex situ. La résistance au chancre chez le noyer n’a pas été établie à ce jour parmi les populations de noyer cendré (Juglans cinerea), mais la conservation de génotypes ex situ potentiellement résistants deviendra de plus en plus importante avec l'accroissement de la fréquence des chancres. Le chêne à gros fruits (Quercus macrocarpa), espèce menacée à cause de la petite taille de sa population, la perte de son habitat et le développement continu, nécessite principalement des efforts de conservation et de reboisement in situ.

Mots clés : hêtre à grande feuilles, chêne à gros fruits, noyer cendré, résistance aux maladies, ex situ, directives de conservation, ressources génétiques, in situ, reboisement, orme d'Amérique

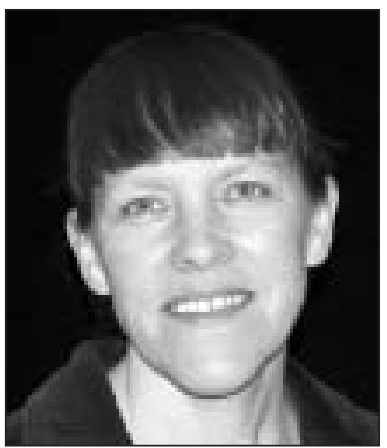

J.A. Loo

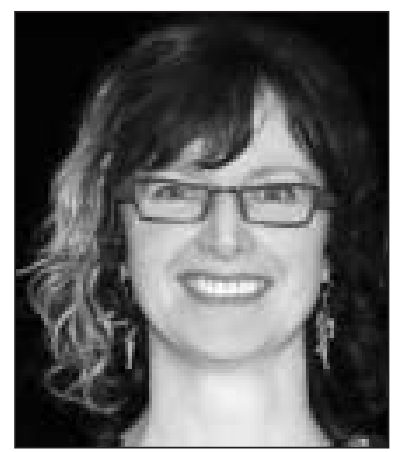

T.L. Beardmore

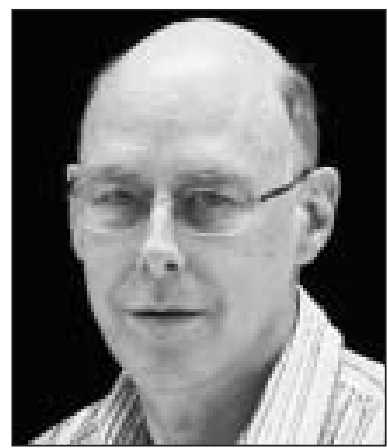

J.D. Simpson

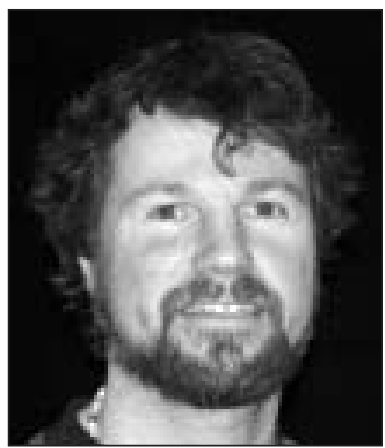

D.A. McPhee

\footnotetext{
${ }^{1}$ Natural Resources Canada, Canadian Forest Service - Atlantic Forestry Centre, P.O. Box 4000, Fredericton, New Brunswick E3B 5P7 and New Brunswick Forest Gene Conservation Working Group.

${ }^{2}$ Author to whom correspondence should be sent. E-mail: jloo@nrcan.gc.ca
} 


\section{Introduction}

Genes are the basic unit of biological diversity, conferring the potential for adaptation to environmental change within species and, at a higher level, marking the differences between species. Globally, relatively little attention has been paid to the loss of biodiversity at the genetic level. Past work undertaken to describe and conserve genetic diversity focused mainly on agricultural crops and their wild relatives. Gene conservation of forest trees was limited to germplasm of commercially important species, identified through tree improvement programs. Currently, the importance of maintaining genetic diversity as a component of ecological sustainability is achieving recognition and, increasingly, gene conservation initiatives address species of ecological importance, as well as those having economic importance (Yanchuk and Lester 1996).

Land development, forest conversion, land clearing for agriculture, and other land-use practices have influenced forest tree populations in New Brunswick (NB) over the past three centuries, diminishing the numbers of some species and providing an opportunity for others to increase (Loo and Ives 2003). Recent concern over the impacts of climate change, especially in combination with introduced pathogens and pests, highlights the vulnerability and importance of forest genetic resources. When vulnerable populations are lost or severely diminished, potentially valuable germplasm is lost.

The New Brunswick Forest Gene Conservation Working Group (hereafter, Working Group) began meeting in 1997 to identify tree species requiring conservation attention at the level of genetic diversity (Powell and Beardmore 2002). In a process described by Loo et al. (2007), criteria were developed to evaluate conservation needs, species were assessed, substantial new research was undertaken to fill knowledge gaps, and conservation guidelines were developed for four NB tree species-American beech (Fagus grandifolia), bur oak (Quercus macrocarpa), butternut (Juglans cinerea), and white elm (Ulmus Americana)_-(Table 1).

Three of the four species, American beech, white elm, and butternut, are threatened primarily by invasive alien species (Houston 1983, Magasi et al. 1993, Ostry 1998). The fourth species, bur oak, is of concern because of its disjunct, scattered distribution, small population size, and diminishing habitat (McPhee 2001). The scope of research undertaken in New Brunswick for these species ranges from developing optimal long-term storage techniques for germplasm to determining the potential for genetic resistance to alien pests (Table 1).

\section{Approach for Developing Guidelines}

Guidelines for gene conservation were developed for the four New Brunswick tree species of greatest concern. The guidelines are based on the type and severity of threats to the species, distribution and level of genetic diversity-where known, currently existing in situ and ex situ conservation and gaps, and restoration potential (Loo et al. 2007). Education, monitoring, and research requirements were identified.

\section{Current in situ and ex situ gene conservation}

With the exception of beech, the four species are not well represented in protected areas (Table 2). Butternut is known to occur in four Protected Natural Areas, but population sizes are unknown. Bur oak is protected only in one small area owned and managed by the NB Nature Trust. Beech is found in many protected areas having hardwood or mixedwood forest ecosystems, but the number of resistant trees in protected areas is unknown. Elm has scattered occurrence along waterways in several parks and other protected areas.

Butternut, beech, and bur oak produce seed classified as recalcitrant. Recalcitrant seeds are intolerant of drying (below 5\% water content) and low temperatures (below freezing), and are, therefore, difficult to store for long periods of time using conventional storage techniques. Recommended storage conditions for Juglans species nuts are at temperatures of $+5^{\circ} \mathrm{C}$ to $-5^{\circ} \mathrm{C}$ under high humidity (i.e., 80-90\%), with viability ranging from six months to two years. Ultra-low-temperature storage using liquid nitrogen (at $-196^{\circ} \mathrm{C}$ ) has been developed for the long-term storage of butternut embryonic axes (Beardmore and Vong 1998). Beech and bur oak seed storage has received less attention to date, but the seed of both species is also difficult to store for more than two years; protocols are under development at the Atlantic Forestry Centre (AFC) for their long-term storage using cryogenic techniques. Seed storage trials for bur oak indicate geographic variation in storage capacity, but viability is low after more than two years in storage for all seed sources collected in NB. Currently, there are no conservation collections for either species, but clone banks are being developed for beech individuals that are putatively resistant to the beech scale (Cryptococcus fagisuga) and more than 120 small restoration plantings of bur oak in the southern part of the province constitute a conservation "collection" although the plantations do not have any official protection.

Elm seed is easily stored. Results indicate little change in viability of elm seed stored for 13 years at $-20^{\circ} \mathrm{C}$ in the National Tree Seed Centre (NTSC). This seed is not currently stored for conservation purposes in the NTSC, but clone banks are being developed at the AFC with material that is putatively resistant or tolerant to Dutch elm disease (DED).

\section{Conservation Guidelines}

Considerations when developing guidelines for conserving genetic resources include the relative emphasis to be given to in situ versus ex situ efforts, identification of populations or material of greatest conservation value, management of in situ conservation sites and methods for ex situ conservation (Table 3), the potential for and approach to restoration, education and outreach, monitoring, and research (Table 4).

Guidelines vary among species in response to different threats. In all cases, research is needed to improve our understanding of ex situ storage techniques. Of the four species of concern, bur oak currently has the smallest distribution and lowest number of trees in NB. However, its conservation and restoration present fewer challenges than the other species because the nature of the threat is well understood and more easily addressed than the others. Bur oak occurrences have been documented in the province and its distribution is well known (McPhee 2001). The other three species are threatened to varying degrees by introduced insects and/or diseases, and the degree and mechanism, as well as mode of inheritance and heritability of resistance to the alien pests, if it exists, are not well understood. Development of reliable ex situ storage techniques is particularly important for each of these species.

Detailed distribution information for butternut and white elm populations or individuals is limited, as is location infor- 
Table 1. Forest tree species in New Brunswick requiring gene conservation and current research

\begin{tabular}{|c|c|c|}
\hline Species & Specific concern & Research activities \\
\hline Butternut (Juglans cinerea) & Butternut canker & $\begin{array}{l}\text { Cryogenic storage, embryogenesis, disease assessment, genetic } \\
\text { diversity }\end{array}$ \\
\hline American beech (Fagus grandifolia) & $\begin{array}{l}\text { Beech bark disease, } \\
\text { harvesting healthy trees }\end{array}$ & $\begin{array}{l}\text { Vegetative propagation, resistance testing, understanding } \\
\text { resistance mechanisms and inheritance, genetic diversity }\end{array}$ \\
\hline White elm (Ulmus americana) & DED & Grafting putatively resistant trees \\
\hline Bur oak (Quercus macrocarpa) & Rarity, habitat loss & $\begin{array}{l}\text { Genetic diversity, restoration protocols, conventional and cryogenic } \\
\text { germplasm storage }\end{array}$ \\
\hline
\end{tabular}

Table 2. Protected areas in New Brunswick having known populations of four forest tree species of concern

\begin{tabular}{llll}
\hline Species & National Parks & Provincial Parks & Protected Natural Areas \\
\hline Butternut & none & Mactaquac & $\begin{array}{l}\text { Hovey Hill, Spednic Lake, Canoose Flowage, Grand Lake } \\
\text { Meadows }\end{array}$ \\
\hline American beech & $\begin{array}{l}\text { Fundy, } \\
\text { Kouchibouguac }\end{array}$ & $\begin{array}{l}\text { Sugar Loaf, Mactaquac, } \\
\text { de la Republique, } \\
\text { Mt. Carleton }\end{array}$ & $\begin{array}{l}\text { Jacquet River, Kennedy Lakes, Mt. Carleton Park Ext., } \\
\text { McCoy Brook, Glazier Lake, Gover Mountain, } \\
\text { Mt. Elizabeth, Hovey Hill, Oak Mountain, Spednic Lake, } \\
\text { Canoose Flowage, Loch Alva, Grand Lake Meadows, } \\
\text { Cranberry Lake, McManus Hill, Point Wolfe River Gorge, } \\
\text { Little Salmon River, Caledonia Gorge, Wilson Brook }\end{array}$ \\
\hline White elm & $\begin{array}{l}\text { Scattered trees } \\
\text { in Fundy and } \\
\text { Kouchibouguac }\end{array}$ & Mactaquac & $\begin{array}{l}\text { Grand Lake Meadows } \\
\text { Bur oak }\end{array}$ \\
\hline
\end{tabular}

aBur oak occurs in one small Nature Trust area, Denton Point, near Grand Lake.

mation for disease-free beech. An unpublished report on tree and shrub species of concern (N. Ives, St. Thomas University, unpublished material) listed 50 database records, four NB Department of Natural Resources map points, and 24 University of New Brunswick herbarium records for butternut. Subsequent media events resulted in unverified information being provided on hundreds of locations of individual or small groups of butternut trees, and the information has been entered into a database at the AFC. Many of the Protected Natural Areas in the province have been surveyed for putatively resistant beech trees and locations have been documented at the AFC as well.

Genetic diversity and adaptive variation patterns specifically for NB populations are unknown for all the species of concern, except bur oak (Loo et al. 2007). In all cases, the pattern of genetic diversity and population genetic structure should inform collection strategies and in situ conservation plans. There is concern that there may be a hybrid component (based on nut morphology) in some NB butternut populations, as has been suggested in other areas (Michler et al. 2005). Before implementing an ex situ conservation program, there is a need to determine which trees or populations have a hybrid component.

\section{Approaches to restoration}

For beech, elm, and butternut, if there is genetic resistance or tolerance to the alien pest or pathogen threatening the species, similar approaches should be effective for identification, propagation, and breeding of resistant genotypes for restoration purposes. Monitoring protocols must be developed, and adopted and applied where each of these species occurs. Butternut trees will need to be monitored as the incidence of disease increases in NB, and healthy trees will be selected as candidates for breeding when a high proportion of surrounding trees has been infected. For elm, live, healthy, uninfected trees larger than $65 \mathrm{~cm}$ diameter at breast height have been selected. Trees that have reached this size would have existed on the landscape when the disease swept through $20+$ years ago, and they may be resistant or tolerant. Selected trees must be clear of epicormic branches on the main stem because experience elsewhere indicates that epicormic branches are not often found on healthy trees that may be resistant to DED (H. Kock ${ }^{3}$, personal communication). Beech

\footnotetext{
${ }^{3}$ Henry Kock was the interpretive horticulturist at the Arboretum, University of Guelph, Guelph, ON.
} 


\begin{tabular}{|c|c|c|c|c|c|}
\hline Species & $\begin{array}{l}\text { Target } \\
\text { populations } \\
\text { to conserve }\end{array}$ & $\begin{array}{l}\text { Relative } \\
\text { effort: } \\
\text { in situ vs. } \\
\text { ex situ }\end{array}$ & In situ conservation focus & $\begin{array}{l}\text { Ex situ conservation methods, } \\
\text { collections }\end{array}$ & Restoration potential \\
\hline Butternut & $\begin{array}{l}\text { Individual trees } \\
\text { showing putative } \\
\text { resistance. }\end{array}$ & 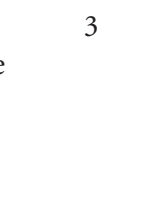 & $\begin{array}{l}\text { All trees that do not show disease } \\
\text { symptoms should be maintained; } \\
\text { will require survey to establish } \\
\text { location and disease status of } \\
\text { individual trees and populations. }\end{array}$ & $\begin{array}{l}\text { Seed cannot be stored using } \\
\text { conventional seed storage methods, } \\
\text { but cryogenic storage of the } \\
\text { embryonic axis has proven successful. }\end{array}$ & $\begin{array}{l}\text { Poor at present; need } \\
\text { to develop genetically } \\
\text { resistant stock. }\end{array}$ \\
\hline
\end{tabular}

\begin{tabular}{|c|c|c|c|c|c|}
\hline $\begin{array}{l}\text { American } \\
\text { beech }\end{array}$ & $\begin{array}{l}\text { Individual trees } \\
\text { showing putative } \\
\text { resistance. }\end{array}$ & 2 & $\begin{array}{l}\text { Disease-free, putatively resistant } \\
\text { trees, in natural and semi-natural } \\
\text { conditions. Best management } \\
\text { practices to increase frequency } \\
\text { of putatively resistant trees by } \\
\text { removing diseased ones. }\end{array}$ & $\begin{array}{l}\text { Seed can be stored using conven- } \\
\text { tional methods, but until the } \\
\text { mode of inheritance of resistance } \\
\text { is understood, resistant genotypes } \\
\text { cannot be conserved by saving seed. } \\
\text { Somatic embryogenesis holds } \\
\text { promise and somatic embryos can } \\
\text { be stored cryogenically. Seed } \\
\text { production can be enhanced using } \\
\text { grafted resistant genotypes in } \\
\text { a seed orchard, when mode of } \\
\text { inheritance is known. Experiments } \\
\text { underway on cryogenic storage of } \\
\text { pollen. }\end{array}$ & $\begin{array}{l}\text { Potential exists if } \\
\text { resistance is durable } \\
\text { and highly heritable, } \\
\text { but considerable work } \\
\text { required to produce } \\
\text { stock. }\end{array}$ \\
\hline
\end{tabular}

$\begin{array}{lll}\text { White elm Individual trees } & 3 \quad \begin{array}{l}\text { Maintain disease-free trees } \\ \text { showing putative }\end{array} \\ \text { resistance. } & \text { for collection of propagation } \\ & \text { material; will require survey to } \\ & \text { establish locations of putatively } \\ & \text { resistant trees. }\end{array}$

Cuttings from as many welldistributed live, healthy, uninfected trees as possible, which are larger than $65 \mathrm{~cm}$ DBH (survived last epidemic), without epicormic branches. Cuttings should be collected in winter for grafting, testing, and establishing seed orchards and/or clone banks.
Poor at present; need to develop genetically resistant stock, if possible.
Seed can not be stored using conventional methods. Experiments

\begin{tabular}{ll}
$\begin{array}{l}\text { old-growth floodplain forest, } \\
\text { thus have high priority; all } \\
\text { populations should be } \\
\text { conserved. }\end{array}$ & $\begin{array}{l}\text { are underway to develop cryogenic } \\
\text { techniques for storage. Ex situ (off } \\
\text { the normal site type) planting is } \\
\text { successful on a variety of sites. }\end{array}$ \\
\hline${ }^{a} 1$ - conservation efforts should be primarily in situ; $2-$ equal emphasis on in situ and ex situ; 3 - primarily ex situ
\end{tabular}

\begin{tabular}{ll}
$\begin{array}{l}\text { old-growth floodplain forest, } \\
\text { thus have high priority; all } \\
\text { populations should be } \\
\text { conserved. }\end{array}$ & $\begin{array}{l}\text { are underway to develop cryogenic } \\
\text { techniques for storage. Ex situ (off } \\
\text { the normal site type) planting is } \\
\text { successful on a variety of sites. }\end{array}$ \\
\hline${ }^{a} 1$ - conservation efforts should be primarily in situ; $2-$ equal emphasis on in situ and ex situ; 3 - primarily ex situ
\end{tabular}

\begin{tabular}{ll}
$\begin{array}{l}\text { old-growth floodplain forest, } \\
\text { thus have high priority; all } \\
\text { populations should be } \\
\text { conserved. }\end{array}$ & $\begin{array}{l}\text { are underway to develop cryogenic } \\
\text { techniques for storage. Ex situ (off } \\
\text { the normal site type) planting is } \\
\text { successful on a variety of sites. }\end{array}$ \\
\hline${ }^{a} 1$ - conservation efforts should be primarily in situ; $2-$ equal emphasis on in situ and ex situ; 3 - primarily ex situ
\end{tabular} $\begin{array}{ll}\text { old-growth floodplain forest, } & \begin{array}{l}\text { are underway to develop cryogenic } \\ \text { thus have high priority; all } \\ \text { populations should be } \\ \text { conserved. }\end{array}\end{array}$

$\begin{array}{llll}\text { Bur oak } \quad \begin{array}{ll}\text { All populations } \\ \text { in New Brunswick. }\end{array} & 1 \quad \begin{array}{l}\text { Trees should not be cut; two } \\ \text { small bur oak populations are } \\ \text { old-growth floodplain forest, } \\ \text { thus have high priority; all } \\ \text { populations should be }\end{array} & \begin{array}{l}\text { Seed can not be stored using } \\ \text { conventional methods. Experiments } \\ \text { are underway to develop cryogenic } \\ \text { conserved. }\end{array} & \begin{array}{l}\text { techniques for storage. Ex situ (off } \\ \text { the normal site type) planting is } \\ \text { successful on a variety of sites. }\end{array} \\ \end{array}$

High potential. in gene banks or seed orchards to produce seed. The clonal gene banks and orchards will constitute ex situ conservation as well as sources of seed or cuttings for propagation. In the absence of information regarding geographic variation within the province for each of the species, it would be desirable to establish clonal orchards-for cutting production for elm and seed production for butternut and beech-for each of the southern ecoregions, with a minimum of 40 clones per orchard.

This approach has merit as long as the few large healthy trees for each species were indeed exposed to the disease and are resistant or tolerant. Grafts of these trees will be screened for resistance or tolerance. Protocols for resistance screening are available for butternut (Ostry and Pijut 2000; D. Bergdahl, 
Table 4. Education, monitoring and research requirements as elements of conservation strategies for four New Brunswick tree species

\begin{tabular}{|c|c|c|c|c|}
\hline Species & Education targets & Main messages & Monitoring & Research required \\
\hline Butternut & $\begin{array}{l}\text { Woodlot owners; } \\
\text { other rural and } \\
\text { urban dwellers; } \\
\text { horticultural } \\
\text { nursery } \\
\text { managers }\end{array}$ & $\begin{array}{l}\text { 1. Species is endangered. } \\
\text { 2. How to identify tree } \\
\text { and canker. } \\
\text { 3. Avoid cutting healthy trees. } \\
\text { 4. Avoid importing nursery } \\
\text { stock. } \\
\text { 5. Monitor and report on } \\
\text { condition. }\end{array}$ & $\begin{array}{l}\text { Evaluate populations and } \\
\text { individual trees in affected areas, } \\
\text { at the edge and in areas that are } \\
\text { still disease free to monitor } \\
\text { progress of the disease annually, } \\
\text { and identify possible resistance. }\end{array}$ & $\begin{array}{l}\text { 1. Does resistance to the canker exist? } \\
\text { 2. Somatic embryogenesis and marker } \\
\text { development to select resistant } \\
\text { genotypes. } \\
\text { 3. Most efficient ex situ storage method } \\
\text { for long term viability of genetic } \\
\text { material. }\end{array}$ \\
\hline $\begin{array}{l}\text { American } \\
\text { beech }\end{array}$ & $\begin{array}{l}\text { Woodlot owners, } \\
\text { Crown and } \\
\text { industrial licensees }\end{array}$ & $\begin{array}{l}\text { 1. Healthy beech has a value. } \\
\text { 2. Healthy trees exist in } \\
\text { natural stands because } \\
\text { of genetic resistance. } \\
\text { 3. Leave healthy trees to } \\
\text { reproduce. }\end{array}$ & $\begin{array}{l}\text { Document clear beech trees in } \\
\text { permanent sample plots, and } \\
\text { evaluate at reassessment } \\
\text { intervals for change in } \\
\text { condition. }\end{array}$ & $\begin{array}{l}\text { 1. Mode of inheritance for resistance. } \\
\text { 2. Molecular basis for resistance. } \\
\text { 3. Best propagation method for resistant } \\
\text { trees. } \\
\text { 4. Genetic diversity and adaptive variation. } \\
\text { 5. Seed storage potential and protocols to } \\
\text { maximize germination. }\end{array}$ \\
\hline White elm & $\begin{array}{l}\text { Urban and rural } \\
\text { population }\end{array}$ & $\begin{array}{l}\text { 1. Potential exists for developing } \\
\text { trees more resistant to disease. } \\
\text { 2. Healthy trees should be } \\
\text { maintained and reported. }\end{array}$ & $\begin{array}{l}\text { Identified mature healthy trees } \\
\text { and trees grown from controlled } \\
\text { crosses or vegetative propagation } \\
\text { of putatively resistant trees should } \\
\text { be assessed periodically for signs } \\
\text { of infection. }\end{array}$ & $\begin{array}{l}\text { 1. Does resistance and/or tolerance to } \\
\text { DED exist in NB trees? } \\
\text { 2. Crossing and resistance screening } \\
\text { protocols. } \\
\text { 3. Geographic patterns of genetic diversity } \\
\text { and resistance. }\end{array}$ \\
\hline Bur oak & $\begin{array}{l}\text { Woodlot owners, } \\
\text { Urban dwellers, } \\
\text { cottage owners, } \\
\text { conservation } \\
\text { organizations } \\
\text { and agencies. }\end{array}$ & $\begin{array}{l}\text { 1. How to recognize bur oak. } \\
\text { 2. Do not harvest trees. } \\
\text { 3. Plant local stock on } \\
\text { appropriate sites. } \\
\text { 4. Local bur oak is a good } \\
\text { choice for city planting. }\end{array}$ & $\begin{array}{l}\text { Monitor natural populations } \\
\text { and restoration sites for genetic } \\
\text { diversity, natural regeneration } \\
\text { success, survival of planted trees, } \\
\text { success, survival of planted trees, } \\
\text { due to development. Seed sources } \\
\text { sold at local nurseries. }\end{array}$ & $\begin{array}{l}\text { 1. Develop ex situ storage methods } \\
\text { for seed. } \\
\text { 2. Evaluate tolerance to air pollution for } \\
\text { use in city planting. }\end{array}$ \\
\hline
\end{tabular}

personal communication ${ }^{4}$ ). When elm grafts are at least $2.5 \mathrm{~m}$ tall, they will be inoculated with Ophiostoma novo-ulmi spores and their response evaluated. Challenge trials have been underway for beech selections throughout southern NB (Ramirez 2005), and this work will be continued to increase the number of resistant clones. Following the screening trials, clones may be established in seed orchards for the eventual production of seed. The clones will need to be evaluated again for resistance, when they are older. The reason for re-evaluation is because there may have been false negative results from the initial evaluation because of the vigour of the grafts, enabling them to combat the disease or the scale insect, in the case of beech. Ultimately, seed or resistant propagules will be supplied to, or produced by, private horticultural nurseries, who would market the seedlings to the public. Collaboration with agencies such as the Elm Research Institute, US National Arboretum, and The Arboretum University of Guelph will be beneficial.

Silvicultural practices are important to maintain healthy trees and viable populations for beech and bur oak. Diseased beech is good firewood and is commonly harvested for that

${ }^{4}$ Dale Bergdahl is a Professor Emeritus of Forest Pathology at the University of Vermont. purpose in small woodlots. If the diseased trees were girdled several years before cutting for firewood there would be less stump and root suckering of disease-susceptible trees (Ostrofsky 2005). On an individual woodlot, where low numbers of putatively resistant trees occur mixed with high numbers of diseased trees, the diseased trees should be gradually removed several years after girdling, if possible. The diseaseand insect-free trees should not be harvested, and additional resistant trees should be planted, when such seedlings are available. In many cases, the resistant individuals in a woodlot are likely to be closely related, so introducing unrelated but local resistant seedlings, when available, will be a good precaution.

Bur oak holds the most promise for restoration, but the existing small populations of mature trees are vulnerable. Most bur oak populations in NB lie within $30 \mathrm{~m}$ of the vegetation line surrounding watercourses (McPhee 2001); therefore, watercourse alteration permits are required by law before any alterations may be made by the landowners. The NB Department of Environment, which is the issuing agency for these permits, is responsible for recognizing the potential importance and value of bur oak sites.

Restoration should begin with planting seedlings using local seed where bur oak populations have likely occurred in 
the past. Ideally, these sites would be chosen in areas that currently host individual or small groups of bur oak trees and would be located between the current populations, producing a bur oak metapopulation (Foose et al. 1995). A metapopulation refers to a system of populations connected by at least occasional dispersal. For bur oak, based on acorn and pollen dispersal distances, along with the high levels of gene flow that occurred in the past (based on our study of mature bur oaks) a $10-\mathrm{km}$ maximum distance is suggested between each population. Maintaining gene flow will also help to improve the species' chances of surviving habitat fragmentation and global change.

Introducing genetic material from other sources is often cited as a management solution to bring small populations up to minimum viable size or to enhance local genetic diversity (Fahselt 1988). If local populations have adapted to environmental conditions, outbreeding depression could result from interbreeding between local and introduced sources (Ellstrand and Elam 1993). To avoid this possibility, nursery managers should be encouraged to use local seed sources, in order to protect local adaptation.

Education is a key aspect of conservation strategies for each of the species, both to make landowners and forest practitioners aware of the need for conservation or special forestry practices and to encourage implementation of restoration plans. Landowners are made aware of the benefits of involvement in programs, such as Conservation Easements or Private Stewardship agreements that are operated under the Fish and Wildlife Branch of NB Department of Natural Resources, through education efforts. These programs allow sites to be protected without compromising ownership. Benefits for the landowners include tax breaks, ease of intergenerational land transfer, and recognition. Guidelines outlined here lend themselves to public involvement, because private citizens may have trees growing on their properties and they can provide anecdotal information about large, living specimens.

\section{Conclusion}

A variety of activities can be undertaken to ensure that genetic resources of these four native NB hardwood tree species are maintained for future ecological and economic benefit. Profound environmental changes are likely during the next century and maintaining the genetic diversity of native tree species is an important, and relatively easy insurance mechanism. All four species are under various degrees of threat in NB and in other parts of their range, and maintaining large resilient gene pools for each of them is an important aspect of any approach to conservation and restoration.

The conservation guidelines described here vary for the four species because of the different nature of the threats they face. Although the guidelines are intended for populations of species of concern in NB, the approach may provide a useful model for other species of concern across the country.

\section{Acknowledgments}

We would like to thank Nadine Ives (St. Thomas University, Fredericton, NB), Peter Salonius, Ed Hurley, and Ken Harrison (Atlantic Forestry Centre) for their comments and review of these guidelines. Also Dr. Michael Dumas, retired research scientist at Natural Resources Canada, Canadian Forest Service - Great Lakes Forestry Centre, Sault Ste. Marie, $\mathrm{ON}$; and Henry Kock, formerly Interpretive Horticulturist at the Arboretum, University of Guelph, ON, provided assistance on the American elm guidelines.

\section{References}

Beardmore, T. and W. Vong. 1998. Role of the cotyledonary tissue in improving low and ultralow temperature tolerance of butternut (Juglans cinerea) embryonic axes. Canadian Journal of Forest Research 28: 1-8.

Ellstrand, N.C. and D.R. Elam. 1993. Population genetic consequences of small population size: implications for plant conservation. Annual Review of Ecological Systems 24: 217-242.

Fahselt, D. 1988. The dangers of transplantation as a conservation technique. Natural Areas Journal 8: 238-244.

Foose, T.J., L. deBoer, U.S. Seal and R. Lande. 1995. Conservation management strategies based on viable populations. In J.D. Ballou, M.Gilpin and T.J. Foose (eds.). Population Management for Survival and Recovery: Analytical Methods and Strategies in Small Population Conservation. pp. 273-294. Columbia University Press, New York.

Houston, D.R. 1983. American beech resistance to Cryptococcus fagisuga. In Proceedings, IUFRO Beech Bark Disease Working Party Conference, 26 Sept.-8 Oct. 1982., Hamden, CT. USDA For. Serv. Gen. Tech. Rep. WO-37.

Loo, J. and N. Ives. 2003. The Acadian forest: historical condition and human impacts. The Forestry Chronicle 79: 462-474.

Loo, J.A., T. Beardmore, J.D. Simpson and D.A. McPhee. 2007. Tree species of concern in New Brunswick, Canada. I. Current status and threats. The Forestry Chronicle 83: 393-401.

McPhee, D. 2001. Status description for bur oak, Quercus macrocarpa, in the province of New Brunswick. MScF Thesis, University of New Brunswick, Fredericton, NB.

Magasi, L.P., D.A. Urquhart, K.J. Harrison and D.M. Murray. 1993. Three decades of Dutch elm disease in Fredericton, N.B.: 1961-1990. Natural Resources Canada, Canadian Forest Service - Atlantic Forestry Centre Information Report M-X-185E. 39 p.

Michler, C.H., P.M. Pijut, D.F. Jacobs, R. Meilan, K.E. Woeste and M.E. Ostry. 2005. Improving disease resistance of butternut (Juglans cinerea), a threatened fine hardwood: a case for single-tree selection through genetic improvement and deployment. Tree Physiology 26: $121-128$

Ostrofsky, W.D. 2005. Management of beech bark disease in aftermath forests. In C.A. Evans, J.A. Lucas and M.J. Twery (eds.). Beech bark Disease: Proceedings of the Beech Bark Disease Symposium. Paul Smith's College, Saranac Lake, 16-18 June 2004. pp. 133-137. USDA Forest Service. Northeastern

Research Station. General Technical Report NE-331.

Ostry, M.E. 1998. Butternut canker in North America 1967-1997. In Proceedings IUFRO WP Foliage, Shoot and Stem diseases in forest trees. Quebec City, QC. 8 p.

Ostry, M.E. and P.M. Pijut. 2000. Butternut: an underused resource in North America. HortTechnology 10: 302-306.

Powell, G. and T. Beardmore. 2002. New Brunswick tree and shrub species of concern: a field guide. Natural Resources Canada, Canadian Forest Service - Atlantic Forestry Centre Information Report M-X-212E. 66 p.

Ramirez, M. 2005. Screening for genetic resistance and vegetative propagation of disease-free American beech (Fagus grandifolia). MScF Thesis. University of New Brunswick, Fredericton, NB. 62 p. Yanchuk, A.D. and D.T. Lester. 1996. Setting priorities for conservation of the conifer genetic resources of British Columbia. The Forestry Chronicle 72: 406-415. 